\title{
Comparative oxygen and carbon isotopic records of Miocene and recent lacustrine unionid bivalves from Poland
}

\author{
Bła ej BŁA EJOWSKI ${ }^{1, *}$, Grzegorz RACKI ${ }^{1,2}$, Piotr GIESZCZ ${ }^{3}$, Krzysztof MAŁKOWSKI ${ }^{1}$, \\ Adrian $\mathrm{KIN}^{4,+}$ and Katarzyna KRZYWIECKA ${ }^{1}$ \\ 1 Institute of Paleobiology, Polish Academy of Sciences, Twarda 51/55, 00-818 Warszawa, Poland \\ 2 Faculty of Earth Sciences, University of Silesia, Będzińska 60, 41-200 Sosnowiec, Poland \\ 3 Association of Polish Climatologists, Krakowskie Przedmieście 30, 00-927 Warszawa, Poland \\ 4 PHACOPS Association of Friends of Geosciences, Łódź, Poland
}

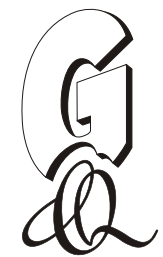

Bła ejowski B., Racki G., Gieszcz P., Małkowski K., Kin A. and Krzywiecka K. (2013) Comparative oxygen and carbon isotopic records of Miocene and recent lacustrine unionid bivalves from Poland. Geological Quarterly, 57 (1): 113-122, doi: 10.7306/gq.1072

The $\delta^{13} \mathrm{C}$ and $\delta^{18} \mathrm{O}$ isotope data from both fossil (Miocene) and modern freshwater bivalve shells of family Unionidae from Poland (species Margaritifera flabellatiformis and Unio tumidus, respectively) show a similar, truncated sinusoidal pattern. The isotopic profiles of the shells are visibly marked by three growth stages, linked with a progressive loss of environmental record because of declining intra-annual biocarbonate accretion rate. The juvenile and gerontic phases exhibit generally more positive and stable (plateau) isotopic pattern than the mid-age stage. An increasing $\delta^{13} \mathrm{C}$ trend is typical for the final life stage, likely influenced by nutrient overloading, reversing the tendency towards ${ }^{13} \mathrm{C}$ depletion throughout the individual's life induced by metabolic processes. Due to the progressive loss of environmental signals through ontogeny, these initial and final isotopic profile segments probably correspond to, respectively, an instant signature of the first season growth, and a multiyear value set of summer maxima during geriatric stage. Vague seasonal cyclic record is the striking feature of the mid-age $\delta^{18} \mathrm{O}$ and $\delta^{13} \mathrm{C}$ profile slices. In case of low-amplitude $\delta^{18} \mathrm{O}$ curve, this is probably promoted by a sensitivity of the lake ecosystem to many dynamic intra-annual factors affecting water budget balance. This consistent signature mode seems to be typical for lake-dwelling unionid shells at least since Miocene from different climatic zones, as confirmed by coeval lacustrine low-latitude mussels from Amazonia. Thus, this isotope record is relevant to obtain information on the habitat and life cycle of the fossil freshwater bivalves, as well as could help to understand modern environmental change.

Key words: sclerochronology, stable isotopes, freshwater, Miocene and recent Unionidae, Bełchatów, Gil Wielki Lake.

\section{INTRODUCTION}

Geochemical data recorded in accretionary biogenic carbonates have been proven to be a useful tool in studies of modern and past environments. The stable oxygen and carbon isotopic composition of these biominerals reflects environmental signals, delivering quantitative information about the habitat during the life-span of a given organism, as exemplified by recent studies on corals (e.g., Leder et al., 1996; Beck et al., 1997), foraminifera (e.g., Bemis et al., 1998; Diz et al., 2009), ostracodes (e.g., Xia et al., 1997), fish otoliths (e.g., Patterson, 1998) and molluscs (e.g., Klein et al., 1996; Dettman et al., 1999; Wurster and Patterson, 2001; Versteegh et al., 2009, 2010; Tao and Grossman, 2010).

\footnotetext{
* Corresponding author: bblazej@twarda.pan.pl

${ }^{\dagger}$ Deceased
}

Received: September 13, 2012; accepted: December 18, 2012; first published online: February 4, 2013
Bivalves, especially marine species, are considered particularly good archives of environmental data (e.g., Khim, 2002; Khim et al., 2003; Ford et al., 2010). During their growth, subsequent layers of calcium carbonate are secreted, and the chemical composition of each growth increment is related to ambient conditions at the time of crystallization (Jones, 1981). Sample sequences analysed along the direction of growth should reflect the life history of a given specimen (sclerochronology). Bivalve molluscs have a worldwide distribution, both in marine and freshwater environments, and due to their abundance allow studies with sufficient spatial and temporal resolution. In particular, the large (up to $20 \mathrm{~cm}$ long; Morris and Corkum, 1999: fig. 3A) freshwater unionid mussels display macroscopically easily identifiable, relatively thick inter-annual growth bands and are especially useful in sclerochronological studies (e.g., Detman et al., 1999; Verdegaal et al., 2005).

Because mussel hard parts usually precipitate in oxygen isotope equilibrium with ambient water (Grossman and $\mathrm{Ku}$, 1986; Wefer and Berger, 1991), their $\delta^{18} \mathrm{O}$ values are related to both the temperature and oxygen isotope composition of the water $\left(\delta^{18} \mathrm{O}_{w}\right.$; see Dettman et al., 1999). The application of stable carbon isotope ratios is more complicated. Early studies 


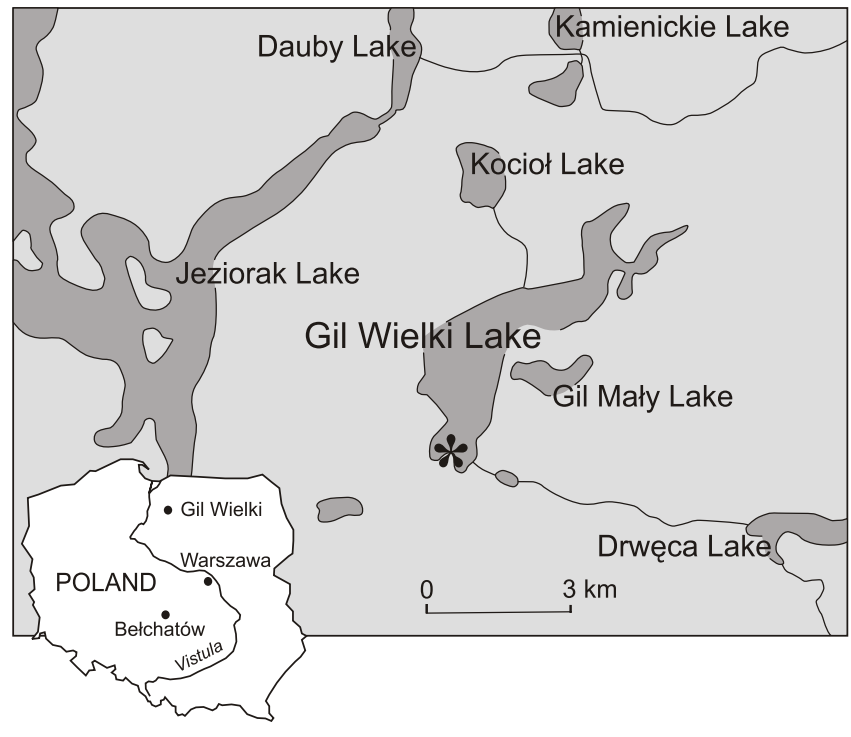

Fig. 1. Locations of bivalve study sites in Poland, and map of the Gil Wielki Lake system, showing shell collection sites (Kormoran Bay, marked by asterisk)

suggested that the dissolved inorganic carbon (DIC) is the only source of carbon in biogenic carbonates (e.g., Mook and Vogel, 1968). However, Dillman and Ford (1982) found that metabolic activity, previously reported as "vital effect" (Urey et al., 1951), also exerts an influence on shell composition and obscures the DIC signal. According to McConnaughey et al. (1997), aquatic invertebrates incorporate less than $10 \%$ respired carbon in their skeletons. Thus vital effects would generally have only a minor influence, but Lorrain et al. (2004), Gillikin et al. (2007, 2009) and Yan et al. (2012) stressed that there is a significant ontogenetic increase of the isotopically light metabolic carbon in some species.

After preliminary analysis of fossil lake-dwelling bivalves from Miocene lignite strata of Belchatów (central Poland; Fig. 1), we observed an isotopic pattern that was hard to explain due to mostly unclear seasonal cyclic signature. We conducted observations in some Masurian lakes for several seasons. We chose locations of our field study as similar to that of ancient lake Bełchatów as possible, including the size, depth and character of basin, and associated biota. After our initial studies we considered the Gil Wielki Lake in Masurian Lake District (Fig. 1) as the most analogous to this temperate Miocene lake. The aim of this study is to present carbon and oxygen stable isotope record in Miocene lake bivalves ( 18 million years ago), and comparison of obtained patterns with those from modern unionid bivalves (according to taxonomic uniformitarianism rule; Dodd and Stanton, 1981). A similar comparative approach in molluscan studies is exemplified by works of Kobashi and Grossman (2003), Tao and Grossman (2010) and Schöll-Barna et al. (2012).

\section{SHELL GROWTH AND ISOTOPIC RECORDS}

Many recent studies show that carbon and oxygen isotopic profiles of bivalve shell material depend not only on host-water chemistry, but also on growth-rate changes over lifespan and sampling resolution (e.g., Khim, 2002; Goodwin et al., 2003; Kaandorp et al., 2003; Khim et al., 2003; Verdegaal et al., 2005; Versteegh et al., 2009). Complete archiving of environmental signals in shell aragonite is precluded by changing intra-annual growth rate, that declines through ontogeny and might be paired finally with frequent accretion halts (e.g., Goodwin et al., 2003). The recurrent dark growth lines result from seasonal interruptions of individual growth during hibernation.

The optimal growth conditions and the onset of spring growth for the Unionidae are controlled dominantly by water temperature, exceeding the individual thermal tolerance in the coldest regimes between 8 and $13.5^{\circ} \mathrm{C}$ (Dettman et al., 1999; Ricken et al., 2003; Versteegh et al., 2010). Therefore, the cyclic $\delta^{18} \mathrm{O}$ profile would be controlled by a combined effect of temperature-related fractionation and winter growth cessation, visible in the carbonate secretion termination at the $\delta^{18} \mathrm{O}$ value minima. Environmental control of oxygen isotopic profile is known from other lakes and rivers (Grossman and Ku, 1986; Goodwin et al., 2003; for exceptions see e.g., Versteegh et al., $2009,2011)$. When water composition is affected mostly by inflow from melting mountain glaciers and snow fields, $\delta^{18} \mathrm{O}$ minima are indicating summer conditions, what is not in the case of lowland lakes, such as Gil Wielki, where summer evaporation causes higher $\delta^{18} \mathrm{O}$ values. This seasonal growth rhythmicity indicates that mostly spring and summer ambient water isotopic composition are imprinted in the annual bands, and that winter signature may be absent (e.g., Verdegaal et al., 2005: p. 405; Versteegh et al., 2009).

In contrast to these prominent, complete and thick increments, less pronounced growth lines are considered to be disturbance bands. The subsidiary lines can possibly be attributed to the effects of non-seasonal temperature water shift, starvation, oxygen deficiency, predation and spawning (see Goewert et al., 2007). Generally a more stable growth is predicted for lakes than river habitats (Schöll-Barna, 2011). Unionid bivalves, being semi-infaunal filtrators, sensitively react to nutrient quality and loading. In addition, the shell growth is sensitive to human-induced pollution of the lake ecosystem (acidification, hypoxia, nutrient overloading and turbidity), and a causal link between shell growth and water temperature is biased in so affected settings (Dunca et al., 2005; Bucci et al., 2009). For example, anoxia as a result of extreme warmth and eutrophication may suppress the seasonal biocarbonate precipitation. Therefore, subsidiary growth disturbances, not related to winter accretion cessation, cause the seasonal signature to be incomplete (Versteegh et al., 2009).

\section{MATERIALS AND METHODS}

Five Miocene mussels from the Szczerców lignite mining field (Bełchatów region) and twenty-five recent molluscs from Gil Wielki Lake in Masurian Lake District (Fig. 2), were selected for analysis of age and growth-rate. To exclude the possibility of diagenetic overprint in the investigated fossil shells, we examined the chosen samples using X-Ray diffraction analysis (XRD). The bulk analysis of powdered shell samples was carried out in Institute of Geological Sciences PAS using Bruker-AXS D8 Advance Series 2 device.

Individuals were chosen from the larger (and presumably of older individual age) size classes of shells that showed no evidence of past injury, predation attempts or serious growth disruption. According to previous studies, indicating a maximum life-span of $\sim 15$ years typical for recent Unionidae bivalves we assume the age of 15 years for these large individuals (see Versteegh et al., 2009; compare Morris and Corkum, 1999). In Polish Masurian lakes representatives of genus Unio are rarely found older than 10 years (Lewandowski and Stańczykowska, 

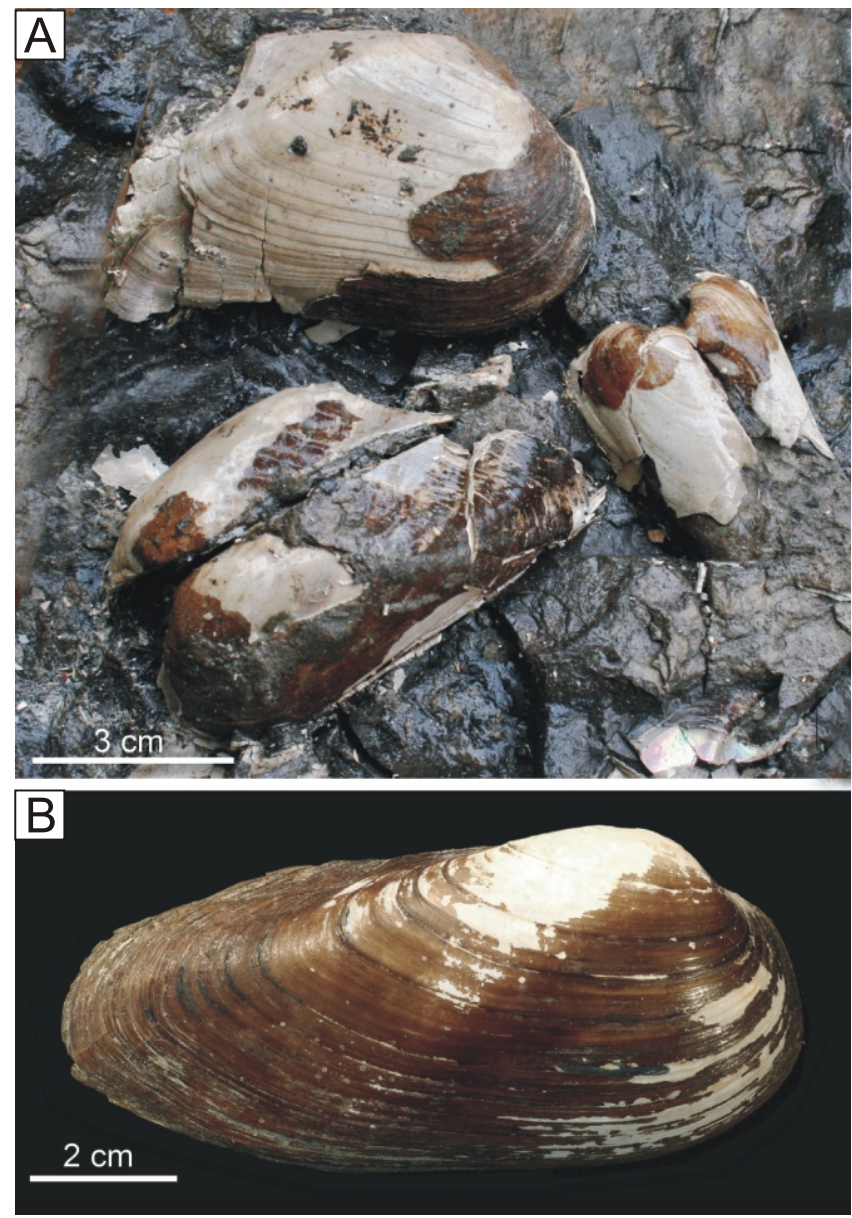

Fig. 2A - Margaritifera flabellatiformis (Grigorovits-Beresovski, 1915) from Bełchatów, Miocene; B - Unio tumidus Philipsson, 1788 from Gil Wielki Lake in Masurian Lake District

1975; Lewandowski, 1990, 1996; Piechocki and DyduchFalniowska, 1993).

From the selected specimens, single valves were completely sampled starting from the umbo to ventral margin along the axis of shell growth. Remaining valves were examined fragmentarily with a lower spatial resolution to reveal any general isotopic trend in the population (see Appendices*). A serial sampling technique was applied to derive a sequence of isotope records from the shells (e.g., Bemis and Geary, 1996; Müller-Lupp, 2002; Müller-Lupp and Bauch, 2005).

Prior to taking carbonate samples, the shell was cleaned to remove any surface contamination. Individual carbonate powder samples $(>50 \mu \mathrm{g})$ were millcut under the binocular microscope sequentially from the outer layer along the axis of maximum growth with a spatial resolution of approximately 0.5 to $1.5 \mathrm{~mm}$, using hand-operated precision drill. To avoid contamination of the sample with material from subjacent shell layers, the sample was milled only from the surface of the outer (prismatic) layer, after periostracum removal.

For stable isotope analysis, the carbonate powder was reacted with $100 \%$ orthophosphoric acid under vacuum at $70^{\circ} \mathrm{C}$ in a KIEL IV carbonate device, which was coupled to a Finnigan MAT Delta Plus isotope ratio mass spectrometer. Isotope ratios are reported in per mil (\%) in the usual delta notation relative to the VPDB standard (defined via NBS 19). The spectrometer ex- ternal error amounts to less than $\pm 0.08 \%$ o. Experiments carried out on sample replicates showed that the average difference between replicates was less than $\pm 0.15 \%$ ofor $\delta^{13} \mathrm{C}$ and $\delta^{18} \mathrm{O}$. All analyses were held at Institute of Geological Sciences PAS.

Unfortunately, environmental and hydrochemical parameters are unavailable for Gil Wielki Lake. For comparison of regional temperature and precipitation with isotopic records in the modern shells, data from the Olsztyn weather station for the last decade (1999-2008) are used. Although Olsztyn is located $55 \mathrm{~km}$ from Gil Wielki Lake, it is the nearest weather station which provides sufficient data record, and was used for comparison in regional scale because it is located within the same climatic region.

\section{REGIONAL SETTING OF THE BIVALVE SITES}

\author{
FOSSIL BIVALVES FROM BEŁCHATÓW
}

The Bełchatów open-pit mine in central Poland $\left(51^{\circ} 15^{\prime} \mathrm{N}\right.$, $19^{\circ} 20^{\prime} \mathrm{E}$ ) is one of the largest lignite deposits in Europe, located within a series of tectonic depressions designated the Kleszczów Graben (Brodzikowski et al., 1987; Krzyszkowski, 1993; Ber and Krzyszkowski, 2004). The graben area, located between Pajęczno (in the western part) and Przedbórz (eastern part), is located within the southern Szczecin-Łódz-Miechów Synclinorium, in the border zone between the Łódź Trough and Miechów Trough (Hałuszczak, 2007). Filling the Kleszczów Graben (combined with a slow subsidence of its bottom), lasted until the Middle Miocene, and at that time was deposited as a succession of coal and clay-coal layers (for details see Ciuk, 1980). According to the lithostratigraphic division, the deposits correspond to the lowest part of the Ścinawa Formation (see Ciuk, 1980). The flora of lowermost brown coal seam is considered to be of Early Eggenburgian age (Early Miocene) whilst the upper part of the main lignite seam contains flora not younger than the Ottnangian (Szynkiewicz, 2000).

Margaritifera flabellatiformis specimens (Grigorovits-Beresovski, 1915), occurring in the lower part of the coal complex, within "black clay section" (BCS), were collected by Adrian Kin in 2007. In this set numerous liners of the green-gray clay have been identified, including also fossil-rich BCS and lacustrine chalk (i.e., gyttjas). The occurrence of these deposits is restricted to a zone of tectonic margin of the Kleszczów Graben. The BCS, occurring usually at the abraded top surface of the Jurassic limestones, contains very numerous, though monospecific, associations of freshwater mussels, indicating periodic mid-forest lakes. Very abundant unidentified plant debris is also commonly found.

\section{RECENT BIVALVES FROM MASURIAN LAKE DISTRICT}

The study was carried out on Unio tumidus Philipsson, 1788 from Kormoran Bay of Gil Wielki Lake (5343'15.2"N, $\left.19^{\circ} 43^{\prime} 34.66^{\prime \prime} E\right)$. It is a post-glacial lake near lława town in northeastern Poland (Fig. 1). The lake surface is 540 ha, maximum depth is $20 \mathrm{~m}$ (Choiński, 1991), but most of the area is shallow-water, averaging $2.5 \mathrm{~m}$ deep. The bottom sediments are very thick ( $>\mathrm{m})$ and contain much organic debris lying loosely on the bottom. The lake's banks are covered with mixed forest, and inflowing Drwęca River has a significant influence on the lacustrine ecosystem.

\footnotetext{
* Supplementary data associated with this article can be found, in the online version, at doi: 10.7306/gq.1072
} 


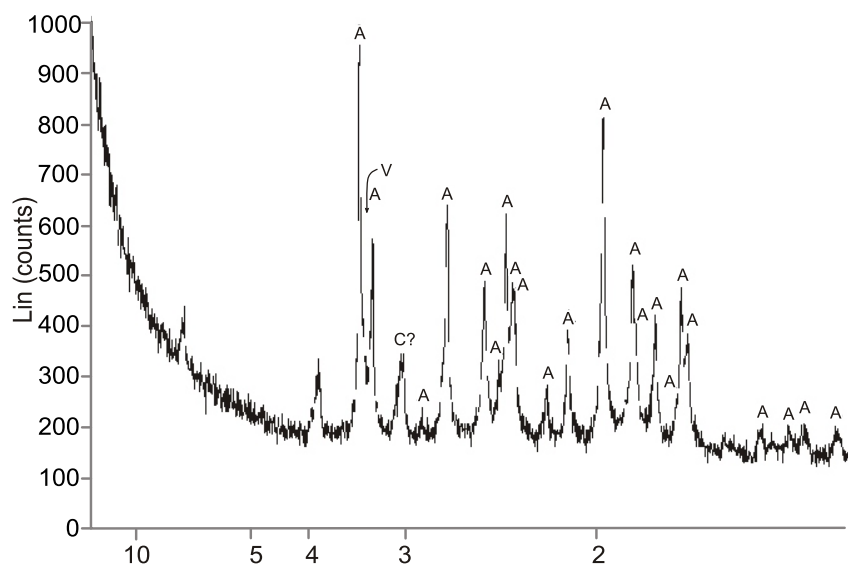

Fig. 3. X-Ray diffraction pattern of Miocene bivalves Margaritifera flabellatiformis shell from Bełchatów

$\mathrm{A}$ - aragonite, $\mathrm{C}$ - calcite, $\mathrm{V}$ - vaterite; the composition of mineral phase indicate, that in shell material aragonite is preserved

\section{RESULTS}

\section{MIOCENE BIVALVES}

The results obtained from XRD analysis indicate that Miocene bivalve Margaritifera flabellatiformis shells from Bełchatów consist entirely of aragonite (Fig. 3), and therefore, oxygen and carbon isotopic compositions (Appendix 1) remain unaltered (e.g., Labonne and Hillaire-Marcel, 2000).

The $\delta^{18} \mathrm{O}$ shell profile (Fig. 4) reveals high but gradually decreasing values (from -5.8 to $6.4 \%$ ) in the earliest growth stage, a great irregular variability in middle segment (dropping to $-7.2 \%$ ), and ultimately a return to relatively constant, moderately high values $(\sim-6.2 \%$ ) during the last phase.

The observed $\delta^{13} \mathrm{C}$ and $\delta^{18} \mathrm{O}$ patterns generally correlates with $r=0.59$ and $p>0.001$. Values are highest in the very first growth phase reaching $-7.6 \%$, followed by fluctuating variation in mid-age encompassing lowest values in the range -7.7 to $-9.2 \%$, and in old age rising consequently again to the highest level of $-7.2 \%$.

Another partly analysed valve reveals similar isotopic patterns in early growth, especially for $\delta^{18} \mathrm{O}$ signature, although the value levels are different (Fig. 4).

\section{RECENT BIVALVES}

The large wild-caught specimen was sampled with maximum spatial resolution, and displayed $\delta^{18} \mathrm{O}$ values ranging from -7.2 to $-4.7 \%$ o during ontogeny (Fig. 5). $\delta^{18} \mathrm{O}$ values show an irregular fluctuating trend with values from $-5.2 \%$ 。 in early growth stages to $-7.2 \%$ o in mid-age, increasing subsequently to $\sim-4.7 \%$ in later life (Fig. 5). Variation in the adult age oxygen isotope ratios contrasts with constant levels in the remaining ontogenic stages, especially during the prolonged gerontic phase. This type of pattern is henceforth called the SVS (semi-constant-variable-semi-constant) pattern.

The variability in $\delta^{13} \mathrm{C}$ values is much greater in living specimens than in fossil shells, and the both isotope ratios do not correlate so strongly $(r=0.32, p=0.02)$. Likewise, the $\delta^{13} \mathrm{C}$ level in juvenile stage, maximally extended to 7 data points, only oscillates around $-6 \%$, whilst showing a high amplitude and rather regular ("sawtooth") fluctuations between -6 and $-12.5 \%$ o over the adult stage. During the last few years of the individual's life, the values increase gradually to $-6.7 \%$, differing noticeably from the time-equivalent $\delta^{18} \mathrm{O}$ plateau. Thus, the ontogeny-related $\delta^{13} \mathrm{C}$ variation is tentatively termed as SFI (semi-constant-fluctuating-increasing) mode.

Other modern specimens sampled with lower resolution show small scatter in the isotopic values, and clearly point that the above described SVS $\left(\delta^{18} \mathrm{O}\right)$ and SFI $\left(\delta^{13} \mathrm{C}\right)$ patterns of isotopic variability during ontogenesis are overall representative characters in the bivalve population (Fig. 6). Some mussel shells displayed slightly higher values of $\delta^{18} \mathrm{O}$ above $-4 \%$ 。 (Fig. 6D), and the maximal $\delta^{13} \mathrm{C}$ values up to $-5 \%$ and the minimal ones to $-14 \%$.

\section{DISCUSSION}

\section{OXYGEN ISOTOPES}

In many studies, $\delta^{18} \mathrm{O}$ values of growth increments in the bivalve shells are verified as a good proxy for host-water temperature, and, implicitly, climate variation (e.g., Dettman et al., 1999; Wurster and Patterson, 2001; Ricken et al., 2003; Verdegaal et al., 2005; Goewert et al., 2007; Versteegh et al., 2009, 2010; Ford et al., 2010; Schöll-Barna et al., 2012).

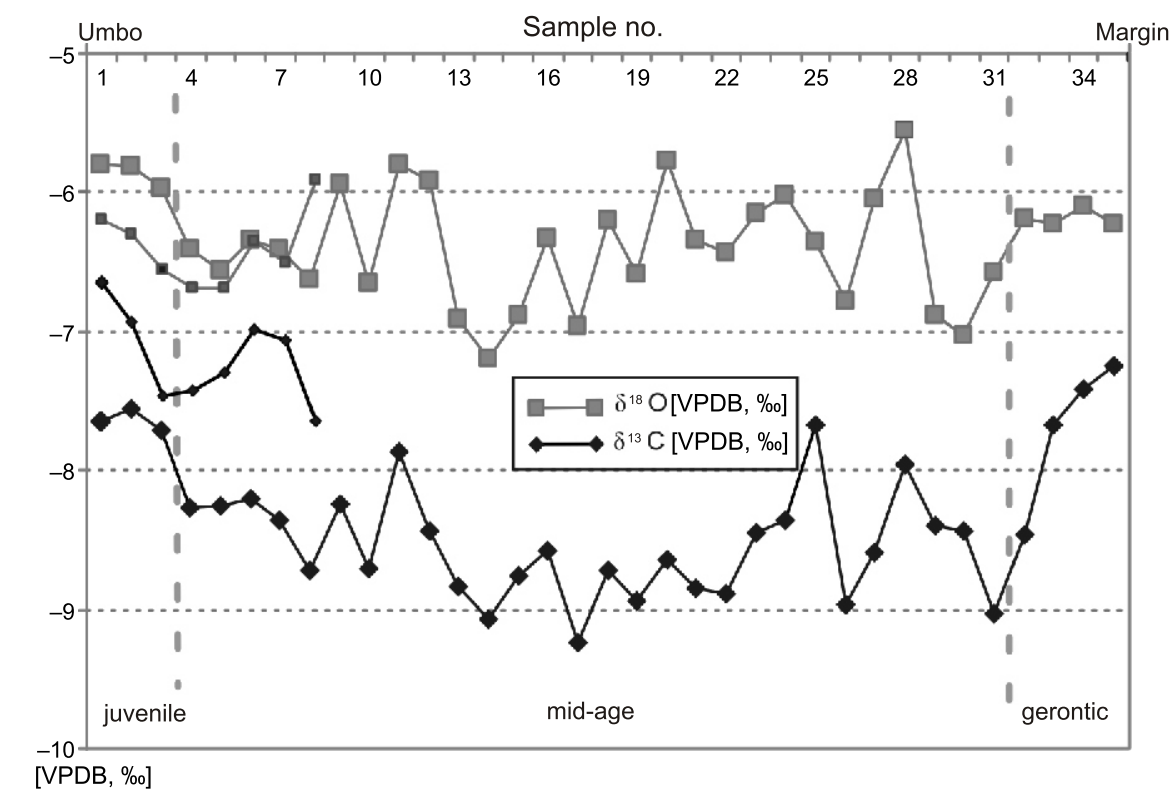

Fig. 4. $\delta^{18} \mathrm{O}$ and $\delta^{13} \mathrm{C}$ patterns for the well-preserved Miocene bivalve shell from Bełchatów

An additional fragmentarily sampled valve (in the umbonal portion) is shown as smaller data points; sample positions are placed in $\mathrm{mm}$ from the umbo to the ventral margin along the axis of shell growth 


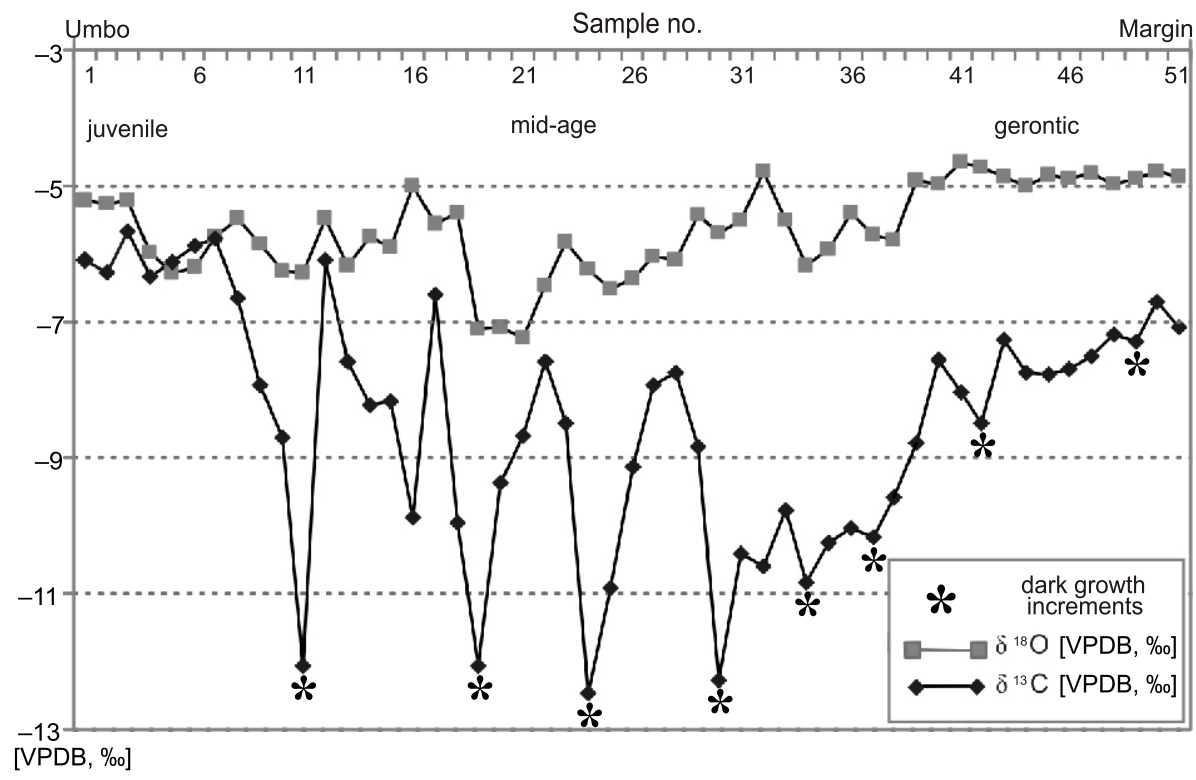

Fig. 5. Representative isotope curves for the recent bivalve Unio tumidus from Gil Wielki Lake
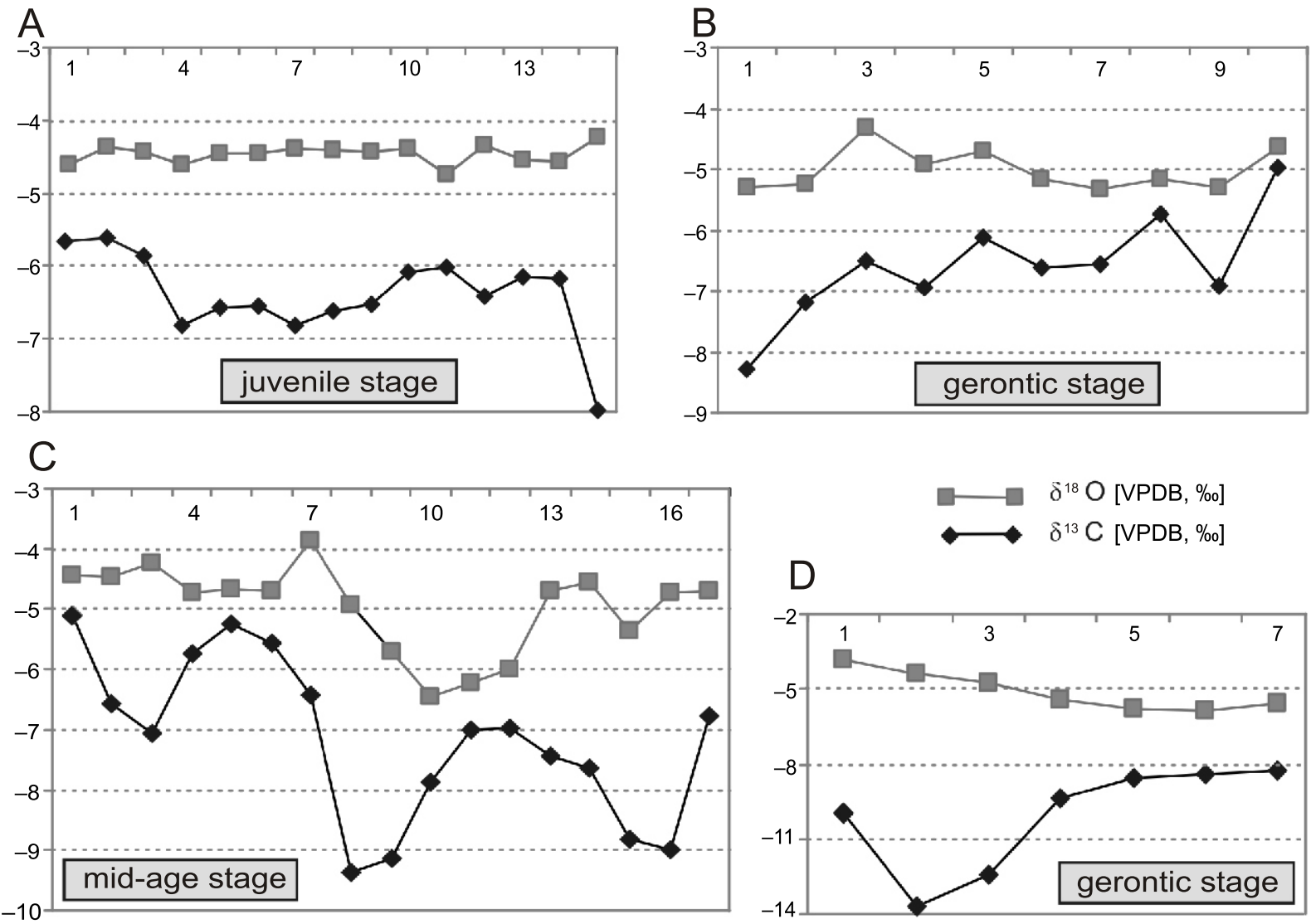

Fig. 6. Isotope curves for fragments of four sampled shells (A-D) of the recent bivalve Unio tumidus from Gil Wielki Lake 


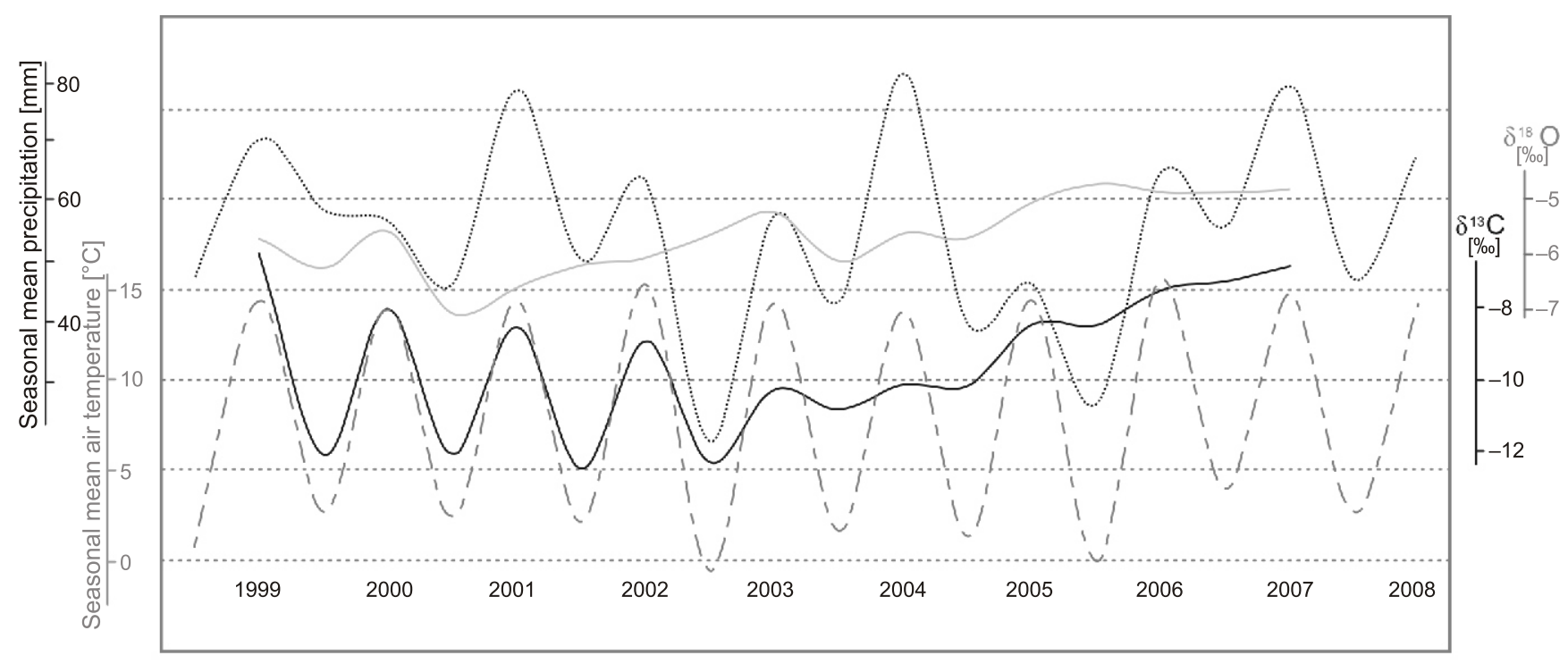

Seasonal mean air temperature and precipitation variability in Olsztyn with isotope record from Gil Wielki Lake

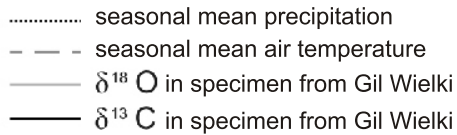

Fig. 7. Smoothed carbon and oxygen isotopic curves of the Masurian bivalve against regional air temperature and rainfall data

Note an increasing multi-seasonal trend recognizable in the both isotopic archives and increasing air temperature versus a stabilized precipitation pattern

The amplitude of $\delta^{18} \mathrm{O}$ values in the investigated fossil specimens is $\sim 1.5 \%$. If this value should be the effect only of the temperature factor, the range of yearly temperature variations would be approximately $6^{\circ} \mathrm{C}$. Taking into consideration that shell aragonite precipitates only above $8^{\circ} \mathrm{C}$, this is quite reasonable (see above). It is, however, hard to explain the evident lack of distinct seasonal periodicity, and other factors should be considered as relevant for $\delta^{18} \mathrm{O}$ variability.

In addition, no distinct rhythmicity considering $\delta^{18} \mathrm{O}$ signature was observed in any studied modern and fossil lacustrine specimen, contrasting with the $\delta^{13} \mathrm{C}$ profiles. Only a first-order warming trend may be confirmed in the Masurian shell record (Fig. 7). Even if the $\delta^{18} \mathrm{O}$ profile of winter maxima and summer minima can be partly obscured by low-resolution sampling, especially in later growth phases, an environmental modulation of this unexpected record is very probable (see e.g., the predicted effect of climate evolution on the Baltic Sea ecosystem; Hordoir and Meier, 2012). Minor accretion disturbances, not related to winter growth shutdowns, are also precluded as a main control (see dark growth lines in Fig. 5). Thus, we should focus on searching for other possible mechanisms to explain observed amplitude and patterns.

For temperate settings, large watersheds are marked by predictable seasonal $\delta^{18} \mathrm{O}_{w}$ cyclicity because of more stabilized water budget, and Wurster and Patterson (2001) stressed the increased susceptibility of the small lakes to storm perturbation in this biogeochemical context. For example, comparably shallow Lake Balaton (mean depth $3 \mathrm{~m}$ ), being relatively dynamic lake ecosystem is also thought after Schöll-Barna (2011) as very sensitive to many climate-related parameters, such as evaporation, precipitation, and river runoffs, influencing oxygen isotope ratios (Schöll-Barna et al., 2012). In addition, the temperature signal contained in sclerochronological record may be to a certain extent modulated by poorly known biologic and met- abolic factors within the extrapallial fluid. For example, specific $\mathrm{pH}$ and carbonate solution chemistry setting, as well as kinetic effects paired with accretion rates are known in intertidal marine mussels (see review in Ford et al., 2010), but this is rather unlikely for unionids. This altogether means that there is no simple interpretation of given isotopic composition profiles, what points out to many factors relevant for $\delta^{18} \mathrm{O}$ variability.

\section{CARBON ISOTOPES}

The $\delta^{13} \mathrm{C}$ values of dissolved inorganic carbon (DIC), available for bivalve shell secretion in freshwater habitats, are chiefly controlled by the interaction of several sources, such as isotopic ratios in inflowing tributaries and ground waters, supply of $\mathrm{CO}_{2}$ from soils (determined by decay of plant matter), and chemical weathering (see summary in Kaandorp et al., 2006). A $\delta^{13} \mathrm{C}$ variation on the order of $0.5 \%$ is considered only as an immediate temperature-modulation effect (Khim, 2002; see also Goewert et al., 2007 and Schöll-Barna et al., 2012).

Seasonal cycling of carbon in lakes is commonly known as forced primarily by the heavy ${ }^{13} \mathrm{C}$ isotope fluctuation due to summer phytoplankton blooming. If the mussel shell would only record DIC isotopic composition, we can expect seasonal cycles repeatedly occurring in the lifetime of given specimen, but potentially shifted due to a vital effect. As shown above, the generalized temporal trend of $\delta^{13} \mathrm{C}$ over all lifetime of an individual is characterized by sequence of descending and ascending values (the SFI pattern; Fig. 8). With exception of first years, but not these earliest ones (Figs. 4 and 5), it is hard to infer any distinct periodicity in isotopic patterns from our unionid shells. On the other hand, even if the contribution of isotopically light metabolic carbon is increasing in the mature age (even to $35 \%$ of shell carbon; Gillikin et al., 2009; Yan et al., 2012), this 
Trend lines of $\delta^{13} \mathrm{C}$ variability

Sample no. (time) along axis of growth

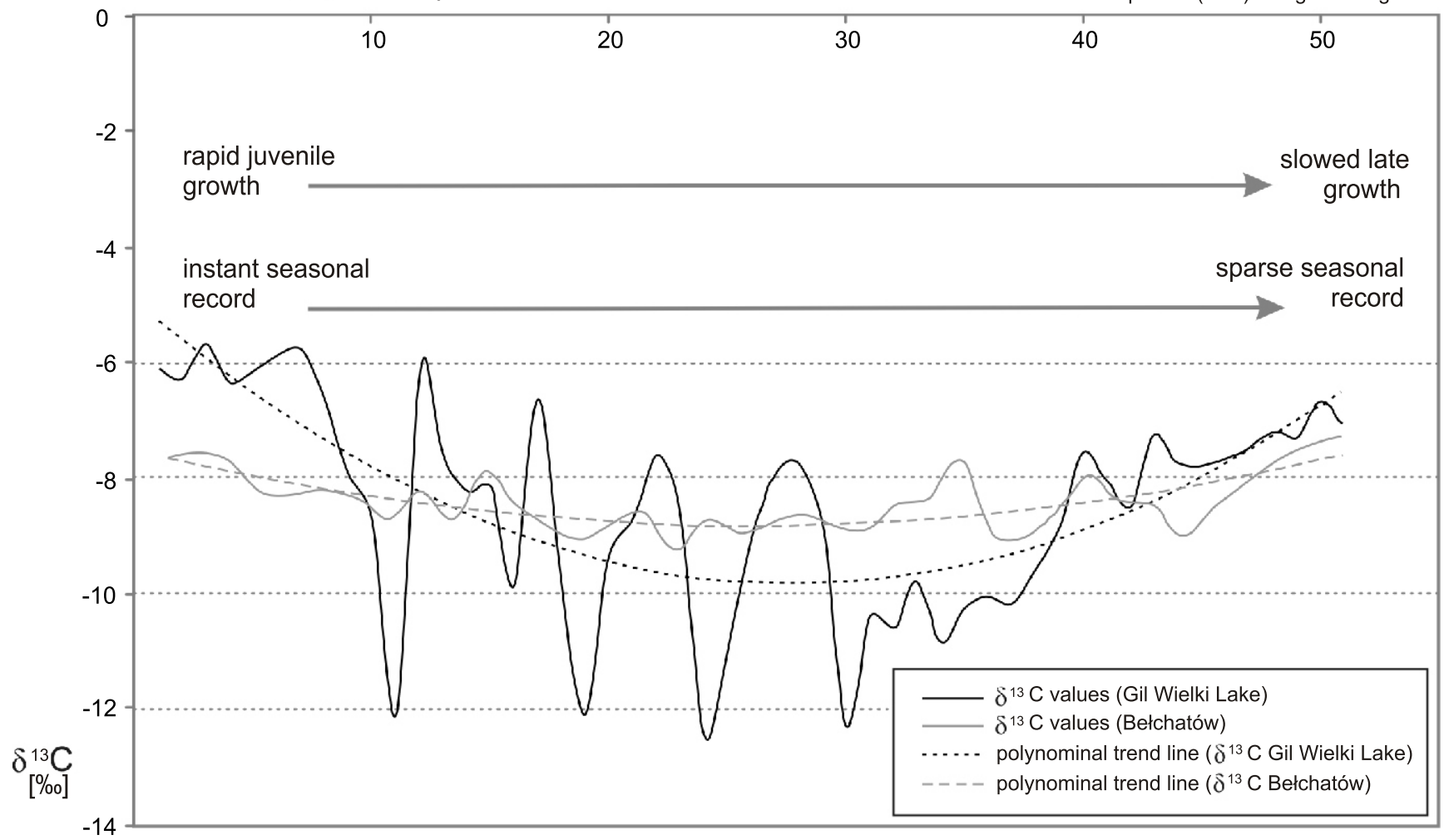

Fig. 8. $\delta^{13} \mathrm{C}$ values and $\delta^{13} \mathrm{C}$ polynomial trend lines derived from Gil Wielki Lake and Bełchatów bivalves

ontogenetic effect is not observed in the shell material characterized by rising of $\delta^{13} \mathrm{C}$ values at the full grown stage, in contrast to a decreasing trend commonly noted in riverine unionid shells (e.g., Verdegaal et al., 2005).

As stressed by Dettman et al. (1999), a correlation between $\delta^{13} \mathrm{C}$ values of unionid aragonite and the $\delta^{13} \mathrm{C}$ of DIC may be essentially absent. The difficulties in interpretation are linked to many quantitatively variable fluxes, such as decomposed organic matter from land, changes in metabolism, and qualitative differentiation in nutrient supply. The issue of influence $\delta^{13} \mathrm{C}$ signatures by individual metabolic signals in freshwater bivalves had been discussed (Geist et al., 2005, see also Schöne et al., 2005). The vital effect offset is not constant and depends on many factors, including food source and nutrition abundance, but it is also changing with age of individual, and it is unclear whether this change is caused directly by physiology or behavioural issues (place of residence). For example, the $\delta^{13} \mathrm{C}$ minima below $10 \%$ measured in Miocene mussels argues decisively for a significant organic matter input into the lake ecosystem.

\section{THREE-FOLD ISOTOPIC PROFILES VS. GROWTH CHARACTERISTICS}

Most research on bivalve molluscs has focused recently on oxygen and carbon isotopic record studied in the context of measured environmental/climatic variables (e.g., Khim et al., 2003; Versteegh et al., 2009, 2010; Ford et al., 2010; Schöll-Barna, 2011; Schöll-Barna et al., 2012). As stressed above, our analysis of $\delta^{18} \mathrm{O}$ isotope profiles across the complete shell time-series shows distinct three-fold (three-stages) multi-year patterns considered as indicating ontogenetically controlled growth variability within the mussels (see modelling results in Goodwin et al., 2003). This distinguishing archiving mode seems to be common for bivalves at least since the Mio- cene (Figs. $3-5$ ). In particular, the $\delta^{13} \mathrm{C}$ values in individual record mark an overall shift towards negative values during life of an individual (Fig. 7), which possibly express "sexual maturation, the initiation of reproduction, and concomitant changes in diet" similarly as suggested in Mesozoic cephalopods (Lukeneder et al., 2010; see also McConnaughey and Gillikin 2008).

As expected, progressively less isotopic information is revealed with advanced bivalve age, meaning that fast accretion took place in the first years of individual life, resulting in the best estimates of environmental signals (e.g., Kaandorp et al., 2003). The juvenile stage in studied mussels is marked by values on semi-constant level in the both isotopic records (Fig. 9A), and we have found similar examples in many other studies especially manifested by $\delta^{18} \mathrm{O}$ profiles of modern unionid species Anodontites trapesialis from an Amazonian floodplain lake (Kaandorp et al., 2003: fig. 4, 2006: fig. 6b; see also Corbicula fluminea from North Carolina in Bucci et al., 2009: figs. 4 and 5). Furthermore, a similar $\delta^{18} \mathrm{O}$ plateau is seen in the premature phase of the Miocene bivalve species Diplodon longulus and Anodontites capax (Kaandorp et al., 2006: fig. 7b). Roughly constant $\delta^{13} \mathrm{C}$ levels in an early growth stage are presented by Verdegaal et al. (2005: fig. 2) for modern Rhine mussels, and for the Miocene Pachynodon tenuis studied by Kaandorp et al. (2006: fig. 8c). In addition, this profile characteristics is also visible in the both isotope ratios in some modern, Pliocene and Eocene shells of the large-sized marine snail Conus (Kobashi and Grossman, 2003: figs. 2 and 4B; Tao and Grossman, 2010: fig. 4).

This isotopic plateau can be explained by a rapid first-year growth of juvenile individual. As pointed out by Kaandorp et al. (2003: p. 347), relatively constant high values prior to the first positive $\delta^{13} \mathrm{C}$ excursion (peak I in fig. 4 a therein; Fig. 9A) sug- 

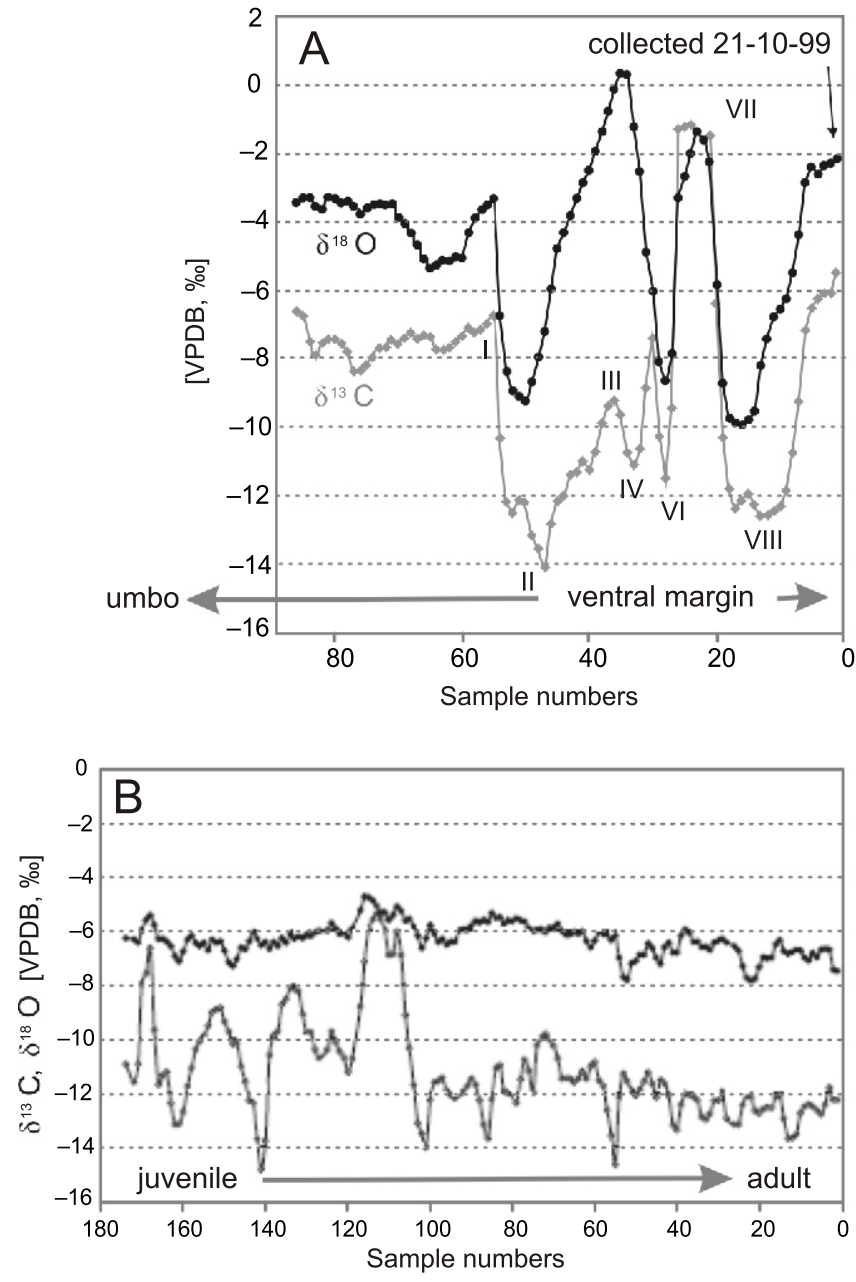

Fig. 9. Semi-constant isotopic record in early (A) and latest (B) growth phases of the Amazonian freshwater bivalves: modern unionid Anodontites trapesialis (after Kaandorp et al., 2003: fig. 4c) and Miocene corbulid Pachynodon tenuis (after Kaandorp et al., 2006: fig. 7c), respectively (compare with Figs. 4-6), used with permission of Elsevier Limited

gest that unionid shells may have grown up to $6 \mathrm{~cm}$ during one season. However, this estimation seems to be extremely high in light of unionid growth curves, as modelled by Morris and Corkum (1999: fig. 3). As an alternative, this may be record of early developmental phase that took place in stable environment when the specimens are completely buried in the sediment (infaunal lifestyle; Negus, 1966; Versteegh et al., 2009), commonly known for the bivalves juveniles in the first $0-4$ years of life (e.g., Strayer et al., 2004; Schwalb and Pusch, 2007).

In the mid-age stage, the $\delta^{13} \mathrm{C}$ curve shows indistinct seasonal pattern with narrow peaks and troughs (Fig. 5). A characteristic high amplitude of $\delta^{13} \mathrm{C}$ and $\delta^{18} \mathrm{O}$ is a possibly related to their sexual maturity, and the effect of habitat and probably diet changes, e.g. at the time of excessive biomass production. The full-grown to gerontic isotopic signature is tentatively interpreted as an effect of progressively shorter growth episodes in the optimal summer temperatures, and therefore it preserves only multiyear pattern of the climate setting (summer maxima) due to prolonged growth halt intervals (see Goodwin et al., 2003). We follow Versteegh et al. (2010: p. 8) that due to recurring winter growth cessations "...$\delta^{18} \mathrm{O}$ records contain (invisible) gaps resulting in juxtaposed increments of (summer) shell growth". In our recent specimens, this highly interrupted growth pattern is reflected by constant values in $\delta^{18} \mathrm{O}$ profiles, probably recording averaged temperature regimes of summer growth season in the lacustrine habitat. This feature seems to be more visible with increasing individual age, although it may be affected by limited sampling resolution in the end of profile. For the probably generally warmer Miocene lake, a more distinctive warming tendency during the individual life may be additionally assumed from decreasing $\delta^{18} \mathrm{O}$ trend.

The increasing $\delta^{13} \mathrm{C}$ trend in the final growth phase remains puzzling, in contradiction with commonly observed contribution of light metabolic carbon in older individual ages. A similar feature is decipherable only in a few living and fossil unionid specimens reported in previous studies (e.g., Kaandorp et al., 2006; see Fig. 9B). Such trend may result from influence of environmental factors as eutrophication and high levels of primary productivity, but modern relationships between the trophic state and malacofauna changes are certainly complex in the Masurian lakes (see example in Kołodziejczyk et al., 2009). Thus, a more accurate environmental interpretation is difficult to perform as strictly related to the particular lacustrine ecosystem. In light of our observations, the SFI isotopic pattern is seen in bivalve shells from only this Masurian locality, while the vital effect overwhelmed the hypothetical positive $\delta^{13} \mathrm{C}$ tendency in other lacustrine habitats. However, this complex matter is beyond the scope of this study and needs extensive ecosystem monitoring data.

\section{CONCLUSIONS AND IMPLICATIONS}

1. Unionid bivalves from Gil Wielki Lake and their Miocene relatives from Bełchatów region have similar trend lines in $\delta^{18} \mathrm{O}$ and $\delta^{13} \mathrm{C}$ record, allowing to distinguish three main profile segments during the life-span of individuals. The principal mechanism of such differentiation is most probably the same in living and fossil bivalves, as confirmed also by $\delta^{18} \mathrm{O}$ and $\delta^{13} \mathrm{C}$ profiles in modern and fossil unionids from low-latitude Amazonian lakes (Kaandorp et al., 2003, 2006). The gross isotopic pattern is explainable mostly by different growth characteristics in early and late age, linked with a progressive loss of environmental sensitivity (Goodwin et al., 2003). Ontogenetical vertical migrations within the watershed may be an additional factor, as well as modulation by metabolic factors.

2. The distinctive three-fold $\delta^{18} \mathrm{O}$ trends are described as the SVS (semi-constant-variable-semi-constant) pattern. The exact contribution of many causes obscuring the seasonal thermal cyclicity in this record are difficult to determine. Sensitivity of the lake ecosystem to many dynamic intra-annual factors affecting water budget balance, such as precipitation/evaporation ratio, relative contributions of groundwater and surface runoff and storminess, is stressed.

3. In case of $\delta^{13} \mathrm{C}$ time series, environmental signal is modulated by physiology and ambient factors, most probably primarily by phytoplankton productivity. Extracting single component from complex signal is difficult, but low contribution of light metabolic carbon in late growth stages is a remarkable character of both modern and fossil mussels. We are therefore unable to resolve processes forcing the $\delta^{13} \mathrm{C}$ variation termed SFI (semi-constant-fluctuating-increasing) pattern. Increasing $\delta^{13} \mathrm{C}$ trend in the late phase may be influenced by significant ecosystem changes, such as nutrient overloading, reversing the vital tendency toward ${ }^{13} \mathrm{C}$ depletion.

4. Vague seasonality in the record is the striking feature of the mid-age $\delta^{18} \mathrm{O}$ and $\delta^{13} \mathrm{C}$ profile segments, and refined analyses based on higher-resolution sampling of the shell material, in 
week to month temporal scale, are necessary. However, this is conclusively confirmed that "molluscs from lakes are less suitable than molluscs from rivers for accurate reconstructions of the seasonal variation of precipitation and evaporation" (Kaandorp et al., 2006: p. 62). Notably in the context, in habitats marked by high human impact, bivalve shell growth is a biased bio-monitor of temperature changes (Dunca et al., 2005).

5. More extensive regional study of the bivalves, supported by monitored ecosystem parameters in several Masurian lakes, would be crucial toward more proper interpretation of the environmental changes in progress (see an advanced warming tendency; Fig. 7), as well as related palaeolimnological issues.
This research agenda refers also to an understanding of shell isotopic signatures in microenvironments related to the behavioural change from infaunal to semi-infaunal habits through early ontogenetic stage.

Acknowledgements. We would like to thank E. Versteegh, K. Lewandowski and A. Skawina for their helpful and insightful review of the manuscript draft. We acknowledge the constructive comments and critical remarks of A. Demény, M. Jasionowski, and four anonymous reviewers. Also we express our thanks to M. Domański for his help in the field works.

\section{REFERENCES}

Beck J.W., Recy J., Taylor F., Edwards L., Cabioch G. (1997) Abrupt changes in early Holocene tropical sea surface temperature derived from coral records. Nature, 385: 705-707.

Bemis B.E., Geary D.H. (1996) The usefulness of bivalve stable isotope profiles as environmental indicators: data from the eastern Pacific Ocean and the southern Caribbean Sea. Palaios, 11: 328-339.

Bemis B.E., Spero H.J., Bijma J., Lea D.W. (1998) Reevaluation of the oxygen isotopic composition of planktonic foraminifera: experimental results and revised paleotemperature equations. Paleoceanography, 13: 150-160.

Ber A., Krzyszkowski D. (2004) Glaciotectonics of the selected regions of Poland (in Polish with English summary). Biuletyn Państwowego Instytutu Geologicznego, 408: 73-125.

Brodzikowski B., Gotowała R., Hałuszczak A., Krzyszkowski D. van Loon A.J. (1987) Soft-sediment deformations from glaciodeltaic, glaciolacustrine and fluviolacustrine sediments in the Kleszczów Graben (central Poland). Geological Society Special Publication, 29: 255-267.

Bucci J.P., Showers W.J., Genna B., Levine J.F. (2009) Stable oxygen and carbon isotope profiles in an invasive bivalve (Corbicula fluminea) in North Carolina watersheds. Geochimica et Cosmochimica Acta, 73: 3234-3247.

Choiński A. (1991) Katalog jezior Polski. Wydawnictwo Naukowe UAM, Poznań.

Ciuk E. (1980) Tektonika rowu Kleszczowa i jej wpływ na warunk powstania zło a węgla brunatnego. Przewodnik LII Zjazdu Polskiego Towarzystwa Geologicznego: 38-56. Wydawnictwa Geologiczne, Warszawa.

Dettman D.L., Reische A.K., Lohmann K.C. (1999) Controls on the stable isotope composition of seasonal growth bands in aragonitic fresh-water bivalves (Unionidae). Geochimica et Cosmochimica Acta, 63: 1049-1057.

Dillman R.M., Ford S.E. (1982) Measurement of calcium-carbonate deposition in mollusks by controlled etching of radioactively labeled shells. Marine Biology, 66: 133-143.

Diz P., Jorissen F.J., Reichart G.J., Poulain C., Dehairs F., Leorri E., Paulet Y.M. (2009) Interpretation of benthic foraminiferal stable isotopes in subtidal estuarine environments. Biogeosciences, 6: 2549-2560.

Dodd J.R., Stanton R.J. (1981) Paleoecology, concepts and applications. J. Wiley and Sons, New York.

Dunca E., Schöne B.R., Mutvei H. (2005) Freshwater bivalves tell of past climates: but how clearly do shells from polluted rivers speak? Palaeogeography, Palaeoclimatology, Palaeoecology, 228: $43-59$

Ford H.L., Schellenberg S.A., Becker B.J., Deutschman D.L., Dyck K.A., Koch P.L. (2010) Evaluating the skeletal chemistry of Mytilus californianus as a temperature proxy: effects of microenvironment and ontogeny. Paleoceanography, 25: 1203.
Geist J., Auerswald K., Boom A. (2005) Stable carbon isotopes in freshwater mussel shells: environmental record or marker for metabolic activity. Geochimica et Cosmochimica Acta, 69: 3545-3554.

Gillikin D.P., Lorrain A., Li M., Dehairs F. (2007) A large metabolic carbon contribution to the $\delta^{13} \mathrm{C}$ record in marine aragonitic bivalve shells. Geochimica et Cosmochimica Acta, 71: 2936-2946.

Gillikin D.P., Hutchinson K.A., Kumai Y. (2009) Ontogenic increase of metabolic carbon in freshwater mussel shells (Pyganodon cataracta). Journal of Geophysical Research, 114: G1:1-6.

Goewert A., Carpenter S.J., Downing J. (2007) Oxygen and carbon isotope ratios of Lampsilis cardium (Unionidae) from two streams in agricultural watersheds of lowa, USA. Palaeogeography, Palaeoclimatology, Palaeoecology, 252: 637-648.

Goodwin D.H., Schöne B.R., Dettmann D.L. (2003) Resolution and fidelity of oxygen isotopes as paleotemperature proxies in bivalve mollusk shells: models and observations. Palaios, 18 : 110-125.

Grossman E.L., Ku T.L. (1986) Oxygen and carbon isotope fractionation in biogenic aragonite: temperature effects. Chemical Geology, 59: 59-74.

Hałuszczak A. (2007) Dike-filled extensional structures in Cenozoic deposits of the Kleszczów Graben (Central Poland). Sedimentary Geology, 93: 81-92.

Hordoir R., Meier H.E.M. (2012) Effect of climate change on the thermal stratification of the Baltic Sea: a sensitivity experiment. Climate Dynamics, 38: 1703-1713.

Jones D.S. (1981) Annual growth increments in shells of Spisula solidissima record marine temperature variability. Science, 211: 165-167.

Kaandorp R.J.G., Vonhof H.B., del Busto C., Wesselingh F.P., Ganssen G.M., Marmo A.E., Romero Pittman L., van Hinte J.E. (2003) Seasonal stable isotope variations of the modern Amazonian freshwater bivalve Anodontites trapesialis. Palaeogeography, Palaeoclimatology, Palaeoecology, 194: 339-354.

Kaandorp R.J.G., Wesselingh F.P., Vonhof H.B. (2006) Ecologica implications from geochemical records of Miocene Western Amazonian bivalves. Journal of South American Earth Sciences, 2: 54-74.

Khim B.K. (2002) Stable isotope profiles of Serripes groenlandicus shells: I. Seasonal and interannual variations of Alaskan coastal water in the Bering and Chukchi Seas. Geosciences Journal, 6: 257-267.

Khim B.K., Kranz D.E., Cooper L.W., Grebmeier J.M. (2003) Seasonal discharge to the western Chukchi Sea shelf identified in stable isotope profiles of mollusk shells. Journal of Geophysical Research, 108: C9: 3300. 
Klein R.T., Lohmann K.C., Thayer C.W. (1996) Sr/Ca and ${ }^{13} \mathrm{C} /{ }^{12} \mathrm{C}$ ratios in skeletal calcite of Mytilus trossolus: covariation with metabolic rate, salinity, and carbon isotopic composition of seawater. Geochimica et Cosmochimica Acta, 60: 4207-4221.

Kobashi T., Grossman E.L. (2003) The oxygen isotopic record of seasonality in Conus shells and its application to understanding late middle Eocene (38 Ma) climate. Paleontological Research, 7: 343-355.

Kołodziejczyk A., Lewandowski K., Stańczykowska A. (2009) Long-term changes of mollusc assemblages in bottom sediments of small semi-isolated lakes of different trophic state. Polish Journal of Ecology, 57: 331-339.

Krzyszkowski D. (1993) Pleistocene glaciolacustrine sedimentation in a tectonically active zone, Kleszczów Graben, Central Poland. Sedimentology, 40: 623-644.

Labonne M., Hillaire-Marcel C. (2000) Geochemical gradients within modern and fossil shells of Concholepas concholepas from northern Chile: an insight into $\mathrm{U}-\mathrm{Th}$ systematics and diagenetic/authigenic isotopic imprints in mollusk shells. Geochimica et Cosmochimica Acta, 64: 1523-1534.

Leder J.J., Swart P.K., Szmant A.M., Dodge R.E. (1996) The origin of variations in the isotopic record of scleractinian corals: I. Oxygen. Geochimica et Cosmochimica Acta, 60: 2857-2870.

Lewandowski K. (1990) Unionidae of Szeszupa River and of the lakes along its course in Suwalski Landscape Park. Ekologia Polska, 38: 271-286.

Lewandowski K. (1996) Występowanie Dreissena polymorpha (Pall.) oraz mał y $z$ rodziny Unionidae $w$ systemie rzeczno-jeziornym Krutyni (Pojezierze Mazurskie). Zeszyty Naukowe Komitetu „Człowiek i Środowisko”, 13: 173-185.

Lewandowski K., Stańczykowska A. (1975) The occurrence and role of bivalves of the family Unionidae in Mikołajskie Lake. Ekologia Polska, 23: 317-334.

Lorrain A., Paulet Y.M., Chauvaud L., Dunbar R., Mucciarone D., Fontugne M. (2004) $\delta^{13} \mathrm{C}$ variation in scallop shells: increasing metabolic carbon contribution with body size? Geochimica et Cosmochimica Acta, 68: 3509-3519.

Lukeneder A., Harzhauser M., Müllegger S., Piller W.E. (2010) Ontogeny and habitat change in Mesozoic cephalopods revealed by stable isotopes $\left(\delta^{18} \mathrm{O}, \delta^{13} \mathrm{C}\right)$. Earth and Planetary Science Letters, 296: 103-114.

McConnaughey T.A., Burdett J., Whelan J.F., Paull C.K. (1997) Carbon isotopes in biological carbonates: respiration and photosynthesis. Geochimica et Cosmochimica Acta, 61: 611-622.

McConnaughey T.A., Gillikin D.P. (2008) Carbon isotopes in mollusk shell carbonates. Geo-Marine Letters, 28: 287-299.

Mook W.G., Vogel J.C. (1968) Isotopic equilibrium between shells and their environment. Science, 159: 874-875.

Morris T.J., Corkum L.D. (1999) Unionid growth patterns in rivers of differing riparian vegetation. Freshwater Biology, 42: 59-68.

Müller-Lupp W. (2002) Gefrier und Tauprozesse im sibirischen Permafrost - Untersuchungsmethoden und ökologische Bedeutung. Berichte zur Polar- und Meeresforschung, 415: 145.

Müller-Lupp T., Bauch H. (2005) Linkage of Arctic atmospheric circulation and Siberian shelf hydrography: a proxy validation using $\delta^{18} \mathrm{O}$ records of bivalve shells. Global and Planetary Change, 48: 175-186.

Negus C.L. (1966) A quantitative study of growth and production of unionid mussels in the river Thames at Reading. Journal of Animal Ecology, 35: 513-532.

Patterson W.P. (1998) North American continental seasonality during the last millennium: high-resolution analysis of sagittal otoliths. Palaeogeography, Palaeoclimatology, Palaeoecology, 138: 271-303.

Piechocki A., Dyduch-Falniowska A. (1993) Mięczaki (Mollusca), Mał e (Bivalvia). Wydawnictwo Naukowe PWN, Warszawa.
Ricken W., Steuber T., Freitag H., Hirschfeld M., Niedenzu B. (2003) Recent and historical discharge of a large European river system - oxygen isotopic composition of river water and skeletal aragonite of Unionidae in the Rhine. Palaeogeography, Palaeoclimatology, Palaeoecology, 193: 73-86.

Schöll-Barna G. (2011) An isotope mass balance model for the correlation of freshwater bivalve shell (Unio pictorum) carbonate $\delta^{18} \mathrm{O}$ to climatic conditions and water $\delta^{18} \mathrm{O}$ in Lake Balaton (Hungary). Journal of Limnology, 70: 272-282.

Schöll-Barna G., Demény A., Serlegi G., Fábián S., Sümegi P., Fórizs I., Bajnóczi B. (2012) Climatic variability in the Late Copper Age: stable isotope fluctuation of prehistoric Unio pictorum (Unionidae) shells from Lake Balaton (Hungary). Journal of Paleolimnology, 47: 87-100.

Schöne B.R., Rodland D.L., Surge D.M., Fiebig J., Gillikin D.P., Baier S.M., Goewert A. (2005) Comment on "Stable carbon isotopes in freshwater mussel shells: environmental record or marker for metabolic activity?" by J. Geist et al. (2005). Geochimica et Cosmochimica Acta, 70: 2658-2661.

Schwalb A.N., Pusch M.T. (2007) Horizontal and vertical movements of unionid mussels in a lowland river. Journal of the North American Benthological Society, 26: 261-272.

Strayer D.L., Downing J.A., Haag W.R., King T.L., Layzer J.B., Newton T.J., Nichols S.J. (2004) Changing perspectives on pearly mussels, North America's most imperilled animals. BioScience, 54: 265-403.

Szynkiewicz A. (2000) Age of the brown coal deposits from the Bełchatów lignite mine (Central Poland) (in Polish with English summary). Przegląd Geologiczny, 48 (11): 1038-1044.

Tao K., Grossman E.L. (2010) Origin of high productivity in the Pliocene of the Florida Platform: evidence from stable isotopes and trace elements. Palaios, 25: 796-806.

Urey H.C., Epstein S., McKinney C.R. (1951) Measurement of paleotemperatures and temperatures of the Upper Cretaceous of England, Denmark, and the southeastern United States. GSA Bulletin, 62: 399-416.

Verdegaal S., Troelstra S.R., Beets C.J., Vonhof H.B. (2005) Stable isotopic records in unionid shells as a paleoenvironmental tool. Netherlands Journal of Geosciences, 84: 403-408.

Versteegh E.A.A., Troelstra S.R., Vonhof H.B., Kroon D. (2009) Oxygen isotopic composition of bivalve seasonal growth increments and ambient water in the rivers Rhine and Meuse. Palaios, 24: 497-504.

Versteegh E.A.A., Vonhof H.B., Troelstra S.R., Kaandorp R.J.G., Kroon D. (2010) Seasonally resolved growth of freshwater bivalves determined by oxygen and carbon isotope shell chemistry. Geochemistry Geophysics Geosystems, 11 (8): 1-16.

Versteegh E.A.A., Vonhof H.B., Troelstra S.R., Kroon D. (2011) Can shells of freshwater mussels (Unionidae) be used to estimate low summer discharge of rivers and associated droughts? International Journal of Earth Sciences, 100 (6): 1423-1432.

Wefer G., Berger W.H. (1991) Isotope paleontology: growth and composition of extant calcareous species. Marine Geology, 100: 207-248.

Wurster C.M., Patterson W.P. (2001) Seasonal variation in stable oxygen and carbon isotope values recovered from modern lacustrine freshwater molluscs: paleoclimatological implications for sub-weekly temperature records. Journal of Paleolimnology, 26: 205-218.

Xia J., Engstrom D.R., Ito E. (1997) Geochemistry of ostracod calcite: Part 2. The effects of water chemistry and seasonal temperature variation on Candona rawsoni. Geochimica et Cosmochimica Acta, 61: 383-391.

Yan H., Li Z.X., Lee X.Q., Zhou H., Cheng H.G., Chen J. (2012) Metabolic effects on stable carbon isotopic composition of freshwater bivalve shell Corbicula fluminea. Chinese Journal of Geochemistry, 31: 103-108. 